\title{
Kinetics and Recovery of Xanthate-Copper Compounds by Ion Flotation Techniques
}

\author{
Martín Reyes, ${ }^{* 1}$ Francisco Patiño, ${ }^{1}$ Francisco J. Tavera, ${ }^{2}$ Ramiro Escudero, ${ }^{2}$ Isauro Rivera, ${ }^{1}$ \\ and Miguel Pérez ${ }^{1}$ \\ ${ }^{1}$ Universidad Autónoma del Estado de Hidalgo, Carretera Pachuca Tulancingo Km 4.5 42184. Pachuca, Hidalgo, México. \\ mreyes@uaeh.edu.mx \\ 2 Instituto de Investigaciones Metalúrgicas Universidad Michoacana de San Nicolás de Hidalgo. Santiago Tapia 403, 58000, \\ Morelia Michoacán, México
}

Received November 7, 2008; accepted March 12, 2009

\begin{abstract}
The recovery of copper in aqueous media by ion flotation in a laboratory flotation cell was carried out. Hydrodynamics and gas dispersion parameters were obtained. The results show that the increase of potassium amyl xanthate concentration above the stoichiometric amount considerably affects the efficiency of the separation of copper. In a stage of flotation with recirculation, recoveries of $58 \%$ and $66 \%$ were obtained with the flat and the cylindrical spargers respectively. The dispersion parameters and bubble surface area flux $\left(\mathrm{S}_{\mathrm{b}}\right)$ show a good relation with the apparent flotation rate constant $(k)$, even when the superficial gas velocity is $0.8 \mathrm{~cm} / \mathrm{s}$, where we can find the appropriate hydrodynamic conditions to carry out the ion flotation. The system subsequently changes from a homogeneous bubble flux to a turbulent flux.

Gas dispersion results show that superficial gas velocity, superficial liquid velocity, dispersion system geometry and the simulated malfunction of spargers considerably affect the recovery of copper in a multi stage system of five flotation cells. The best recoveries were obtained at low superficial gas velocities, achieving efficiencies of $94 \%, 90 \%$ and $95 \%$ with the flat, cylindrical and battery of four spargers respectively.
\end{abstract}

Keywords: Keywords: Ion flotation, Xanthate, Gas holdup, Copper, recovery.

\section{Introduction}

Ion flotation is a technology that uses special properties found in the interfaces in order to concentrate ions or other species with electric charge contained in aqueous solutions [1].

Since 1960, when Felix Sebba introduced the ion flotation concept, extensive research has been carried out on the separation of several of the metal ions found in solution $[2,3]$.

Ion flotation involves the elimination of inactive surface ions (metal ions) from the solutions by adding organic chemical collectors, with gas bubbles being generated in the solution [4]. This results in the formation of a colloidal solid complex that contains the metal and the collector as chemical constituents.

Ion flotation is a complex physico-chemical process which first of all depends on the collector amount and on the chemical manipulation of the system to optimize the recovery of aqueous metals.

Several researchers have studied the type and concentration of active surface reagents (collector) by using long hydro-
Resumen. Se llevó a cabo la recuperación de cobre contenido en medio acuoso por flotación iónica en una celda de flotación de laboratorio. Se obtuvieron los parámetros de la dispersión de gas e hidrodinámica del sistema. Los resultados muestran que el incremento de la concentración de xantato amílico de potasio por arriba de la cantidad estequiométrica afecta considerablemente la eficiencia de separación de cobre. En la flotación iónica en una etapa con recirculación se obtuvieron recuperaciones del 58 y $66 \%$ para el dispersor plano y cilíndrico, respectivamente. Los parámetros de la dispersión, el flujo de superficie de burbujas $\mathrm{Sb}\left(\mathrm{s}^{-1}\right)$ tienen buena correlación con la constante cinética de flotación aparente $k\left(\mathrm{~min}^{-1}\right)$, esto hasta un valor de la velocidad superficial de gas de $0.8 \mathrm{~cm} / \mathrm{s}$, donde se tienen condiciones hidrodinámicas adecuadas, donde el sistema cambia de un flujo de burbujas homogéneo a uno turbulento.

Los resultados de la dispersión de gas muestran que la velocidad superficial de gas, la velocidad superficial de líquido y la geometría del sistema de dispersión, afectan significativamente la recuperación de cobre acuoso en un sistema multi etapas de cinco celdas de flotación. Las mejores recuperaciones obtenidas se obtuvieron a bajas velocidades superficiales de gas, logrando eficiencia de 94, 90, y 95 $\%$ para el dispersor plano, cilíndrico y batería de cilíndricos, respectivamente.

Palabras clave: Flotación iónica, xantato, gas retenido, cobre, recuperación.

carbon chain compounds with limited or no water solubility $[5,6,7]$. However, the hydrodynamic influence and dispersion properties in the recovery of metal ions by means of ion flotation have not been evaluated.

Many successful ion flotation techniques have been identified for separating several metallic elements of the periodic table from dissolved aqueous solutions (Hualing and Zhine, 1989) [8]. Ion flotation has been widely used at laboratory scale in the recovery of metals such as $\mathrm{Cu}, \mathrm{Cr}$, and $\mathrm{Ag}$ [9]; it has been also used to recover silver from X-ray film effluents [10] and to selectively recover gold [11]. Another metal that has been treated with ion flotation is Ge [12]. Cadmium has been also removed from liquid effluents by ion flotation. Polyamide-complexed nickel is another metal that has been successfully removed from aqueous solutions [13]. However, despite the hard work carried out by researchers around the world, the experimentation has been performed in micro-scale equipment, like the Hallimond tube or the batch systems, and little has been done in continuous systems, evaluating the dispersion properties in the recovery. 
Ion flotation has been increasingly used in environmental processes to control the heavy metal ions in industrial effluents or to recover metal ions, especially from lixiviation solutions [4].

Considering the mentioned factors and the poor understanding of the effects of the gas dispersion phenomena on the $\mathrm{Cu}^{++}$recovery by means of ion flotation in laboratory scale equipment, we consider useful to develop experimental work in order to understand the effect of the variables Eg, Jg, and Jl, dispersion system geometry and simulated malfunction of the spargers on the elimination of the metal from the solution.

A study of the copper separation from aqueous solutions diluted by ion flotation techniques in a continuous system was carried out by recirculation of the solution during the entire experimental part in the flotation cell. A surfactant and anionic collectors (potassium amyl xanthate) were used. Several experimental parameters were studied and related directly to the metal ion's recovery.

\section{Experimental procedure}

Figure 1 shows the installation of the flotation cell where the laboratory experiments were carried out; it is a transparent acrylic cell of $33 \mathrm{~cm}$ height and $19 \mathrm{~cm}$ diameter.

In order to regulate the gas input into the flotation equipment, a calibrated flux meter was used. The air was introduced through three different sparger arrangements (the spargers are made of synthetic cloth): Flat, cylindrical and a battery of four spargers. They were placed on the cell's bottom, as shown in Figure 2, which shows the general arrangement of the spargers in the equipment.

The feeding and discharge rates were controlled by two previously calibrated Masterflex peristaltic pumps (1-8 lt $/ \mathrm{min})$. The pump intakes were placed on opposite sides. The cell was operated at a continuous regime. The first experiments were

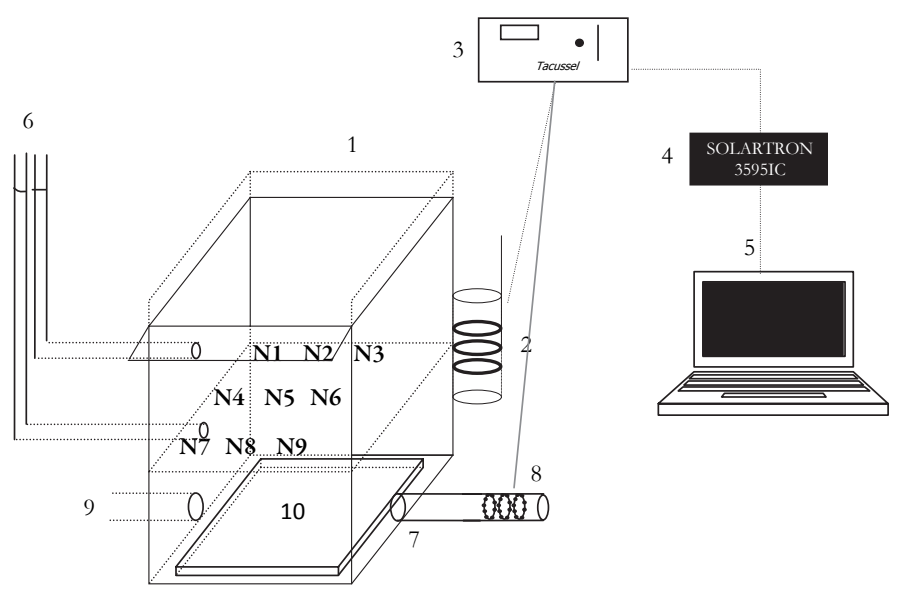

Fig. 1. Schematic Representation of the flotation device: (1) Cell, (2) electrical conductivity flow cell, (3) conductivity meter, (4) data acquisition system. (5) Computer, (6) manometers, (7) tailings stream, (8) electrical conductivity flow cell placed in the tailings stream (9) Feed (10) flat sparger.

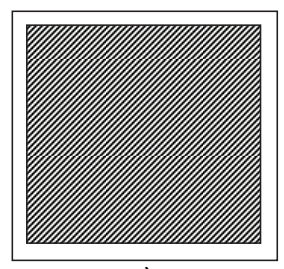

a)

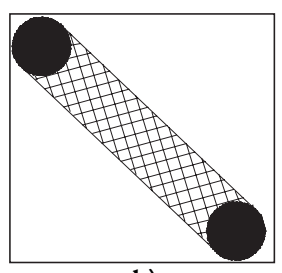

b)

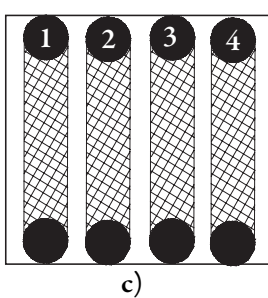

c)
Fig. 2. Schematic disposition of the gas dispersion in the flotation cell, plant view; a) Flat sparger, b) cylindrical and c) battery of four spargers.

performed by recirculating the solution in one tank; a second series of experiments was carried out in a five-cell bank, where each stream, concentrate, tails and feeding had an independent tank.

Cupric sulphate synthetic solutions were prepared for the experimental tests in order to have aqueous phase concentrations of the copper ion of $20 \mathrm{mg} \mathrm{L}^{-1}$. We used propylene glycol 400 as surfactant in concentrations of $30 \mathrm{mg} \mathrm{L}^{-1}$. The anionic collector potassium amyl xanthate was used in the first experiments in concentrations of 63.51.32. 19 and $6.3 \mathrm{mg} \mathrm{L}^{-1}$; a constant concentration of $19 \mathrm{mg} \mathrm{L}^{-1}$ was used in the multi stage system.

The solution was fed and discharged in the equipment at similar superficial liquid velocities for both streams when the system was stable in regards of Jg and $\mathrm{Jl}$ operation variables (these parameters are defined as the volumetric flow relation of gas and liquid $\mathrm{cm}^{3} / \mathrm{s}$, divided by the transversal section area of the equipment $\mathrm{cm}^{2}$, resulting in $\mathrm{cm} / \mathrm{s}$ units). The ion flotation process efficiency was analyzed in function of the concentrates, tails, and feeding samples, thus measuring the sampling time and weighing the taken sample. This process was repeated for each Jg studied value. The samples were collected at intervals of twice the residence time [equation (1)]; they were diluted and their copper content was analyzed by a Perkin-Elmer 3100 Atomic Absorption Spectrophotometer.

$$
\tau=\frac{V z c}{Q_{g}}\left(1-\varepsilon_{g}\right)
$$

Where Vzc is the volume of the collection zone, Qg is the gas volumetric flow $\left(\mathrm{cm}^{3} / \mathrm{s}\right)$ and $\left(1-\varepsilon_{\mathrm{g}}\right)$ is the liquid's fraction. In these experiments, the copper recovery in the concentrates was estimated in function of a mass balance from the samples' chemical analysis, expressing the results in copper grams per minute. According to equation (2),

$$
\% \mathrm{R}=\frac{\mathrm{FM}_{\mathrm{Cu}} \text { concentrate }}{\mathrm{FM}_{\mathrm{Cu}} \text { concentrate }+\mathrm{FM}_{\mathrm{Cu}} \text { tailings }} * 100
$$

For the series of multi stage experiments, the recovery was estimated through the accumulative recovery of every flotation stage, given by equation (3) 


$$
\% \mathrm{R}=\frac{\mathrm{FM}_{\mathrm{Cu}} 1+\mathrm{FM}_{\mathrm{Cu}} 2 \ldots \ldots . . \mathrm{FM}_{\mathrm{Cu}} n}{\mathrm{FM}_{\mathrm{Cu}} 1} * 100
$$

The gas holdup was continuously monitored by using two methods: hydrostatic pressure and electrical conductivity. The procedure by pressure differences was performed on a length section " $L$ " in the collection zone, measuring the height differences with two manometers installed on the flotation cell's side. The fraction of gas holdup in its simplest form (air system-water- surfactant) is given, under these conditions, by equation (4), where $\Delta H$ is the height difference between both pressure takings.

$$
\varepsilon_{g}=\frac{\Delta H}{L}
$$

The conductivity method consisted of collecting data in different cell sections by using an electrical conductivity flow cell $[14,15]$. The sensor was connected to a conductivimeter (Tacussel CDVR62), and the gas holdup is given by equation (5), where $k_{d}$ is the dispersion conductivity, and $k_{l}$ is the liquid's conductivity.

$$
\% \varepsilon_{g}=\left\{\frac{\left[1-\left(\frac{\kappa_{d}}{\kappa_{l}}\right)\right]}{\left[1+0.5\left(\frac{\kappa_{d}}{\kappa_{l}}\right)\right]}\right\} * 100
$$

The electrical conductivity flow cell was placed in the collection zone (on the same level as the two pressure takings) at nine different positions.

The bubble specific surface area flux $\mathrm{Sb}$, with unit times ${ }^{-1}$, is a parameter that considers the effect of the bubble size (which depends on the chemistry, hydrodynamics and characteristics of the bubble generator) and the superficial gas velocity (which depends on the machine's characteristics and on the operating conditions). It is defined as the amount of bubble surfaces moving in a transversal section area by time unit. Besides, experimental data on residence time, mixing time and recirculation were obtained.

\section{Results and discussion}

\section{Residence time distribution}

The residence time distribution (RTD) was measured by the electrical conductivity method using an electrical conductivity flow cell with graphite electrodes $[16,17]$. We used $0.5 \mathrm{~L}$ of saturated solution of potassium chloride as a tracer; it was injected into the flotation cell and the electrical conductivity variations were registered every second for nine minutes by a data acquisition system. The conductivity flow cell was placed in the tailings stream. The most important result in the RTD experiments is the residence time measurement.

Another reason for carrying out these RTD experiments was the characterization of the liquid phase's dynamic behavior in the flotation equipment. Figure 3 presents the results of the RTD tests for the flat sparger at different superficial liquid velocities $\mathrm{Jl} \mathrm{cm} / \mathrm{s}$, Jg of $0.8 \mathrm{~cm} / \mathrm{s}$ and $30 \mathrm{mg} \mathrm{L}^{-1}$ of surfactant. The obtained curves are common to the perfect mixing regime $[16,17]$. In a system that presents perfect mixing with a residence time $(\tau)$, the flotation rate constant [17] is given by equation (6).

$$
k=\frac{R}{(1-R) * \tau}
$$

Where, for a system in perfect mixing regime, the injected tracer is immediately dispersed in the total volume of the equipment. It can be seen on Figure 3, where a part of the tracer instantaneously leaves the flotation cell, while another part leaves the cell after a long period of time, which means that there is an RTD from zero to infinity.

We observed differences between the estimated RTD and measured RTD, indicating that there are zones with dead volumes and phase recirculation, but the residence time distribution has a general perfect mixing behavior.

\section{Ion flotation in one stage}

The reaction mechanism of the copper and of the potassium amyl xanthate, which takes place in the flotation process, is as follows: The cupric sulphate reacts with xanthate to yield cupric xanthate.

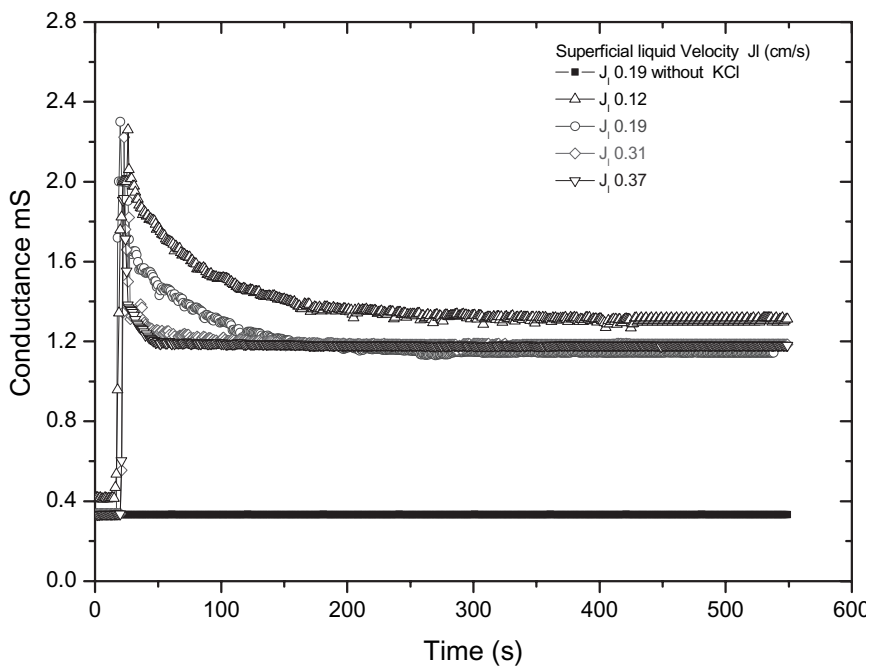

Fig. 3. Residence time distributions for liquid at several superficial liquid velocities. Flat sparger; $\operatorname{Jg} 0.8 \mathrm{~cm} / \mathrm{s}, 30 \mathrm{mg} \mathrm{L}^{-1}$ of Propilenglycol as surfactant. 


$$
\mathrm{Cu}^{2+}+2 \mathrm{~S}=\mathrm{C} \searrow_{\mathrm{OR}}^{\mathrm{SK}^{+}} \rightarrow 2 \mathrm{~K}^{+}+\mathrm{Cu}\left(\begin{array}{c}
-\mathrm{S}-\mathrm{C}-\mathrm{OR} \\
\| \\
\mathrm{S}
\end{array}\right)_{2}
$$

Cupric xanthate, which is unstable, subsequently breaks down into cuprous xanthate and dixanthogen:

$$
2 \mathrm{Cu}\left(\begin{array}{c}
-\mathrm{S}-\mathrm{C}-\mathrm{OR} \\
\| \\
\mathrm{S}
\end{array}\right)_{2} \rightarrow \mathrm{Cu}_{2}\left(\begin{array}{c}
-\mathrm{S}-\mathrm{C}-\mathrm{OR} \\
\| \\
\mathrm{S}
\end{array}\right)+\underset{\mathrm{OR}}{\mathrm{S}=\mathrm{C}-\mathrm{S}-\mathrm{S}-\mathrm{C}=\mathrm{S}}
$$

The cuprous xanthate is once again oxidized to cupric xanthate by the oxygen that was injected into the flotation cell; cupric hydroxide is also formed.

$\mathrm{Cu}_{2}\left(\begin{array}{c}-\mathrm{S}-\mathrm{C}-\mathrm{OR} \\ \mathrm{I} \\ \mathrm{S}\end{array}\right)_{2}+1 / 2 \mathrm{O}_{2}+\mathrm{H}_{2} \mathrm{O} \rightarrow \mathrm{Cu}\left(\begin{array}{r}-\mathrm{S}-\mathrm{C}-\mathrm{OR} \\ \| \\ \mathrm{S}\end{array}\right)_{2}+\mathrm{Cu}(\mathrm{OH})_{2}$

Then, the cupric hydroxide, which is more soluble than the cupric xanthate, reacts with the potassium amyl xanthate, yielding cupric xanthate.

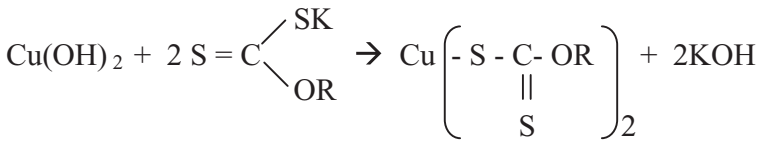

Once more, the cupric xanthate breaks down into cuprous xanthate and dixanthogen; the total cycle continues in this way, and more xanthate is oxidized by the injected oxygen.

Figures 4 and 5 present the xanthate concentration and the $\mathrm{Jg}(\mathrm{cm} / \mathrm{s})$ increase effect in the recovery for the flat and cylindrical spargers respectively. Along with the increase of the gas flow rate, there is an almost linear behavior of the xanthate-copper complexes' separation; this linearity subsequently drops at higher $\mathrm{Jg}$ values (more than $0.8 \mathrm{~cm} / \mathrm{s}$ ). The experimental results show that the gas holdup rises with the $\mathrm{Jg}$ increase (Fig. 6); therefore the bubble diameter decreases for both systems. However, this increases the bubble circulation and coalescence.

Increase in the collector concentration brings a competition between the copper-xanthate complexes and the uncomplexed collector molecules for positions on bubble surfaces, presenting difficulties in the separation of the desired species. The excess of xanthate in the copper ion flotation and the circulation of bubbles produced by Jgs above $0.8 \mathrm{~cm} / \mathrm{s}$ lead to inappropriate hydrodynamic conditions, resulting in poor recoveries in the one-stage flotation.

Experimental observations have shown that the presence of $30 \mathrm{mg} \mathrm{L}^{-1}$ of surfactant tends to keep the spherical shape of the ascending bubbles in the flotation cell. We also found that, when having small bubbles of less than $1 \mathrm{~mm}$ diameter, the rise velocity decreases; in the absence of surfactant, however, the bubbles take irregular shapes and experience violent oscillations, which trigger the mixing and circulation of the continuous and disperse phases.

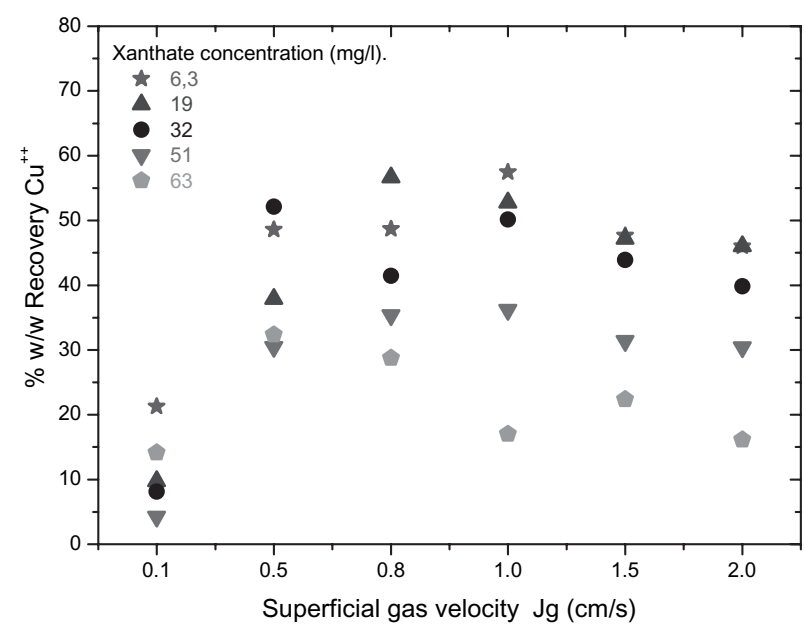

Fig. 4. \% W/W Recovery $\mathrm{Cu}^{++} v s$. superficial gas velocity Flat sparger, $30 \mathrm{mg} \mathrm{L}^{-1}$ of propylenglycol, $\mathrm{Jl} 0.19 \mathrm{~cm} / \mathrm{s}$ at several concentrations of amyl xanthate potassium.

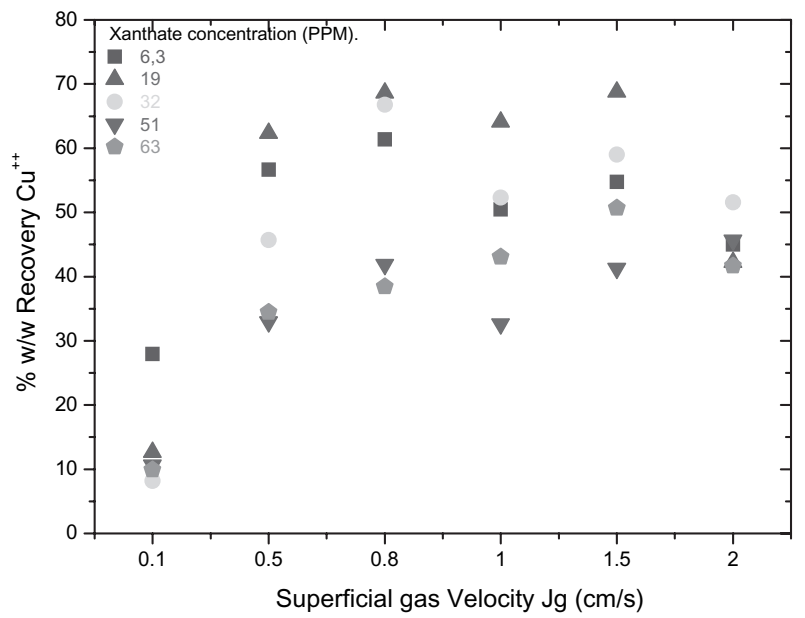

Fig. 5. \% W/W Recovery $\mathrm{Cu}^{++}$vs. superficial gas velocity, cylindrical sparger, $30 \mathrm{mg} \mathrm{L}^{-1}$ of propylenglycol, Jl $0.19 \mathrm{~cm} / \mathrm{s}$ at several concentrations of amyl xanthate potassium.

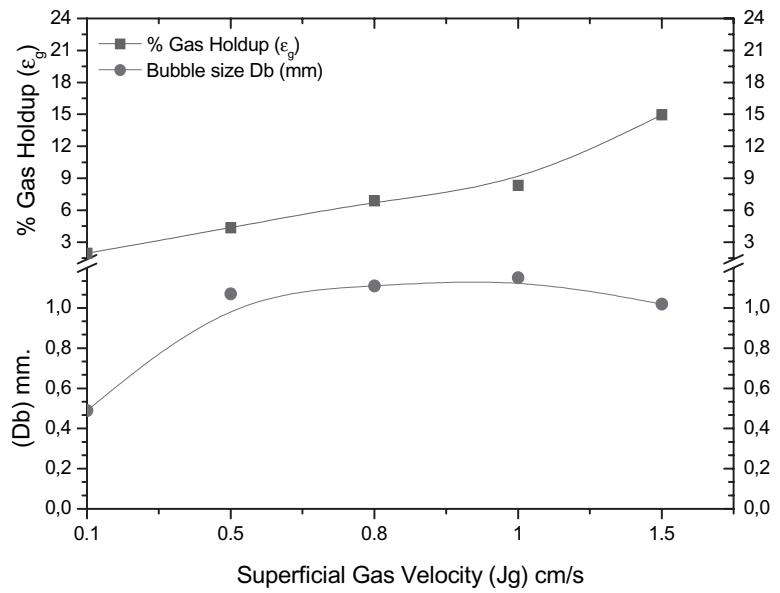

Fig. 6. Gas Holdup (\%) and Bubble size (mm) vs. Superficial gas velocity $\mathrm{Jg}(\mathrm{cm} / \mathrm{s})$. Flat sparger, $30 \mathrm{mg} \mathrm{L}^{-1}$ of propylenglycol, Jl 0.19 $\mathrm{cm} / \mathrm{s}$ with $19 \mathrm{mg} \mathrm{L}^{-1}$ of amyl xanthate. 
It can be observed that a bubble size of approximately $1.0 \mathrm{~mm}$ is obtained in the linear region of $\varepsilon_{\mathrm{g}}-\mathrm{Jg}$ (Fig. 6). Jg values below $0.8 \mathrm{~cm} / \mathrm{s}$ generate slightly smaller bubble sizes. Small diameter bubbles have low rise velocities, and that is why the bubbles' residence time in the flotation cell increases; besides, small bubbles can be easily recirculated in the flotation cell. Consequently, the mass transfer rate decreases from the collection zone to the froth zone; as a result the recovery decreases too.

We found that, under Jg conditions of 0.1 to $0.8 \mathrm{~cm} / \mathrm{s}$, the apparent flotation rate constant $(k)$ of the copper ion has a linear behavior with the $\mathrm{Jg}$ and $\mathrm{Sb}\left(\mathrm{s}^{-1}\right)$ (Fig. 7). In ore flotation, a higher bubble surface area flux usually means a higher probability to achieve the maximum recoveries [17]. In ion flotation, however, higher $\mathrm{Sb}$ values mean unfavorable hydrodynamic conditions to achieve good recoveries in a flotation cell with spargers. For that reason, Jg values above $0.8 \mathrm{~cm} / \mathrm{s}$ cause a drop in the apparent flotation rate constant.

The recovery of copper-xanthate complexes by ion flotation is a process that follows first order kinetics. Recovery depends on three variables: 1) A mixing parameter, 2) Average residence time, and 3) Rate constant $k\left(\mathrm{~min}^{-1}\right)$ [17]. The first parameter was determined from figure 3 , obtaining a flux pattern of the perfect mixing type. Points 2 and 3 were obtained from equations 1 and 6 respectively. Figure 7 presents the results on the apparent flotation rate constant $k\left(\mathrm{~min}^{-1}\right)$ and on the copper recovery in function to the $\mathrm{Jg}(\mathrm{cm} / \mathrm{s}) \cdot k\left(\mathrm{~min}^{-1}\right)$ and recovery have similar behaviors. There is a similar behavior in all of the experiments when plotting $k\left(\mathrm{~min}^{-1}\right)$ in function of the dispersion properties $\left(\varepsilon_{\mathrm{g}}, \mathrm{Db}\right.$ y $\left.\mathrm{Sb}\right)$.

\section{Multi stage ion flotation system}

Figure 8 presents the copper recovery curves at different gas superficial velocities under the following conditions: $20 \mathrm{mg} \mathrm{L}^{-1}$ of $\mathrm{Cu}, 30 \mathrm{mg} \mathrm{L}^{-1}$ of surfactant and $19 \mathrm{mg} \mathrm{L}^{-1}$ of potassium amyl xanthate. The data are presented as mass flux percentages of the copper accumulative recovery in function of the number of flotation stage. The best separation efficiencies were achieved in the fifth stage at a Jg of 0.5 and $0.8 \mathrm{~cm} / \mathrm{s}$ with the flat sparger; this confirms the results obtained in the one-stage flotation, where better recoveries are achieved with lower Jg values.

As a result of the multi stage flotation, gas holdup and recovery percentage decrease drastically in each flotation stage for every test. In every experiment the gas holdup was obtained from measuring the electrical conductivity of an average of nine readings in different positions in the flotation cell. Figure 9 presents the $\mathrm{v} / \mathrm{v} \%$ of gas holdup in function of the number of flotation stage; in this figure we can clearly make the difference in gas holdup at Jg values of 0.5 and $1.5 \mathrm{~cm} / \mathrm{s}$.

Therefore, higher Jg values cause stronger mixing flows in the flotation cell, resulting in longer bubble residence times; the recovery estimated in each flotation stage then decreases along with the apparent flotation rate constant, as seen on figure 10 . The $k$ values were obtained from equation (13), implying a decrease in the mass transfer rate from the collection

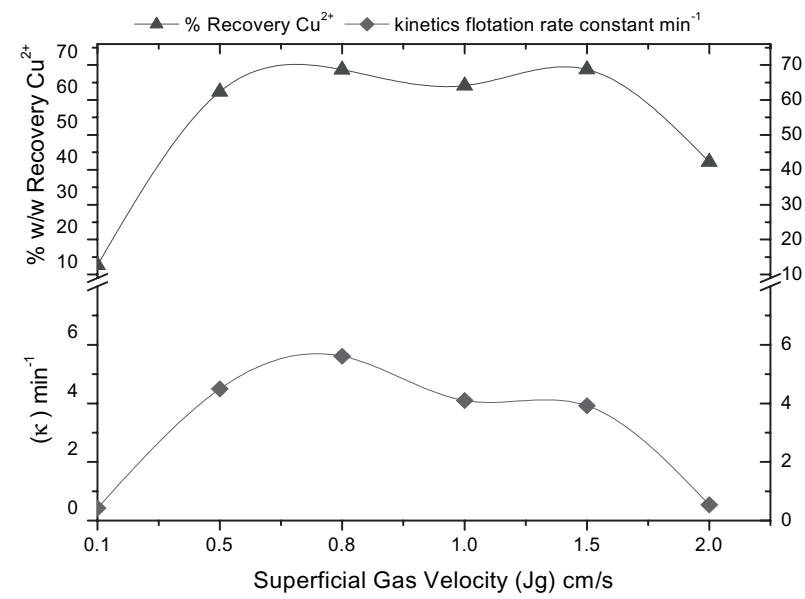

Fig. 7. \% W/W Recovery and apparent flotation rate constant $k\left(\mathrm{~min}^{-1}\right)$ Vs. Superficial gas velocity. Jl $0.19 \mathrm{~cm} / \mathrm{s}$, Flat Sparger, $19 \mathrm{mg} \mathrm{L}^{-1}$ of xanthate, $30 \mathrm{mg} \mathrm{L}^{-1}$ of surfactant.

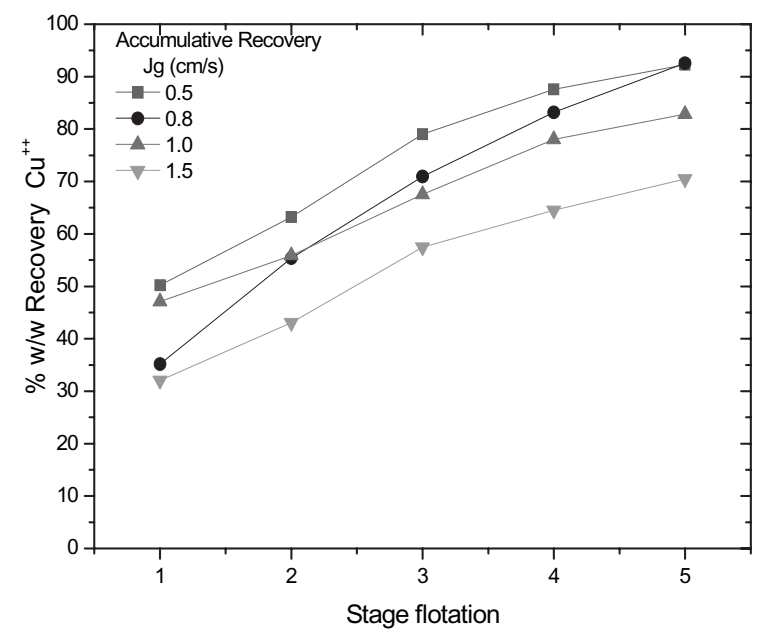

Fig. 8. $\% \mathrm{~W} / \mathrm{W}$ Recovery $v s$. Flotation stage. At several Superficial gas velocities J1 $0.19 \mathrm{~cm} / \mathrm{s}$, Flat Sparger, $19 \mathrm{mg} \mathrm{L}^{-1}$ of xanthate, 30 $\mathrm{mgL}^{-1}$ of surfactant.

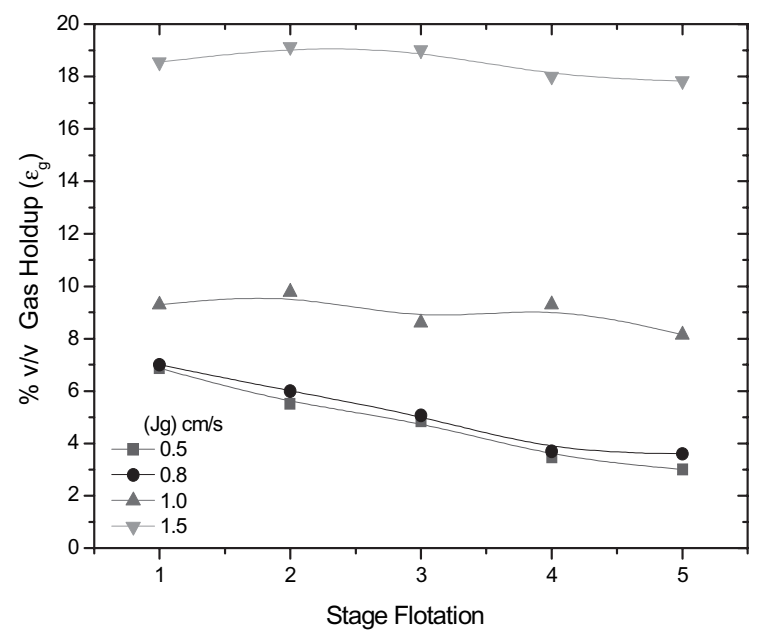

Fig. 9. \% V/V Gas Holdup vs. Superficial gas Velocity $J g(\mathrm{~cm} / \mathrm{s})$. Ion flotation multi stage system, $20 \mathrm{mg} \mathrm{L}^{-1}$ of $\mathrm{Cu}^{2+}$, 19 of xanthate and 30 of frothier, flat bubbler. 
zone to the froth zone; the efficiency of the collection process consequently decreases. That is why gas superficial velocities above $1.0 \mathrm{~cm} / \mathrm{s}$ affect the separation of copper-xanthate complexes in solution; similar results were found with the cylindrical sparger.

We found that the ion flotation process' efficiency in terms of the kinetics constant can be related to the following parameters: bubble size, gas holdup, gas superficial velocity and bubble specific surface flux with Jg values from 0.1 to 0.8 $\mathrm{cm} / \mathrm{s}$. The results are similar for the three used dispersion systems (flat, cylindrical and battery of four spargers).

\section{Effect of the liquid superficial velocity $\mathrm{JI}$}

Figure 11 shows the effect of the liquid superficial velocity on the copper recovery for the flat sparger; it can be observed that in the fifth stage the same recoveries are achieved with higher $\mathrm{Jl}$ values (around 94\%), clearly accelerating the flotation rate. Optimal recoveries are achieved in relatively short periods.

Similar curves of the accumulative recovery percentage are presented for all the experimental tests in multi stage sytems. The best conditions for ion flotation of copper-xanthate complexes were achieved at a Jg of $0.8 \mathrm{~cm} / \mathrm{s}$, Jl of 0.37 $\mathrm{cm} / \mathrm{s}, 19 \mathrm{mg} \mathrm{L}^{-1}$ of xanthate and $30 \mathrm{mg} \mathrm{L}^{-1}$ of surfactant.

Figure 12 presents the results of analogous experiments, but this time using a cylindrical sparger and a battery of four spargers. We can observe, for the series of experiments with the cylindrical sparger at a $\mathrm{Jl}$ of $0.31 \mathrm{~cm} / \mathrm{s}$, better recoveries than the ones obtained at a $\mathrm{Jl}$ of $0.19 \mathrm{~cm} / \mathrm{s}$; all of this because of the high processing rate and the short residence time of the continuous and disperse phases. However, at a Jl of $0.37 \mathrm{~cm} / \mathrm{s}$, the recovery has a drastic drop for both dispersion systems. The reasons are the circulation stream's increase and the disperse and continuous phases' mixing. We found that the best recovery $(96 \%)$ was obtained at the fifth stage for the battery of four spargers at a Jl of $0.19 \mathrm{~cm} / \mathrm{s}$.

In each ion flotation stage, the gas bubble sparger generates additional bubble surfaces for the separation of copper-xanthate from the bulk solution; with each flotation stage a determined amount of $\mathrm{Sb}$ (bubble specific surface flux) is obtained, so the sum of the Sb values of every stage is the amount of $\mathrm{Sb}$ necessary to achieve recoveries of $96 \%$. In order to obtain similar recoveries in one only stage it would be necessary to have a sparger that generates $\mathrm{Sb}$ values of around 500 $\mathrm{s}^{-1}$, with bubble sizes of around $0.01 \mathrm{~mm}$ and a Jg of $0.83 \mathrm{~cm} / \mathrm{s}$ according to $\mathrm{Sb}=6 \mathrm{Jg} / \mathrm{Db}$. The spargers used in this experimental work don't have those characteristics, and we observed that there were parts of the sparger's surface that didn't generate bubbles.

It is clear that with each flotation stage, amounts of froth are produced and spilled. This causes not only the decrease of copper concentration in the solution but also a decrease in the surfactant and xanthate molecules. With the decrease of the reagents' concentration, a decrease in the elimination rate of the copper - xanthate complex during the multi stage flotation is only normal. Besides, the solution's superficial tension

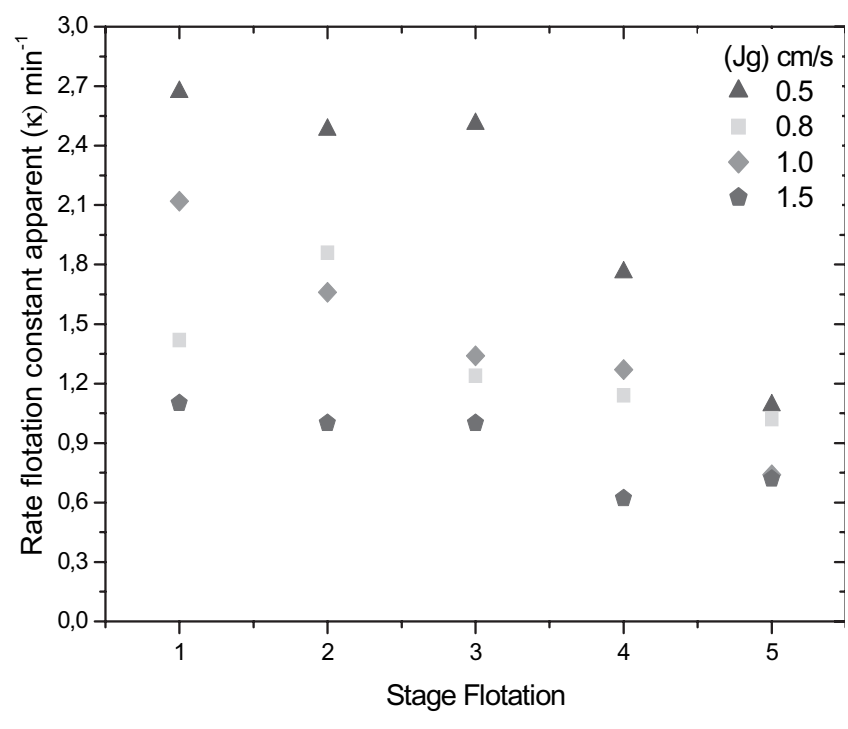

Fig. 10. Apparent flotation rate constant $k \min ^{-1} v s$. Flotation stage, Jl $0.19 \mathrm{~cm} / \mathrm{s}$, Flat sparger, 19 of xanthate, 20 copper and $30 \mathrm{mg} \mathrm{L}^{-1}$ frothier.

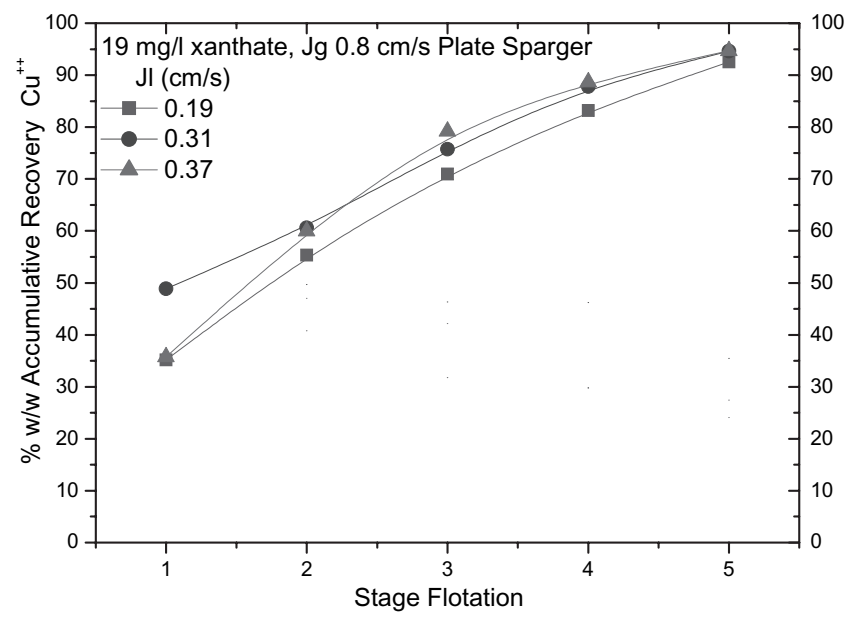

Fig. 11. $\% \mathrm{w} / \mathrm{w}$ Accumulative Recovery $\mathrm{Cu}^{2+} v s$. Flotation stage. At several Superficial gas velocities Flat sparger, Jg $0.8 \mathrm{~cm} / \mathrm{s}, 19 \mathrm{mg} \mathrm{L}^{-1}$ of xanthate.

increases; it was estimated by a bubble formation procedure [19]. Figure 13 shows how the superficial tension increases along with the stage number.

Figure 14 presents the results of the recovery in every stage at a Jg of $0.8 \mathrm{~cm} / \mathrm{s}, 19 \mathrm{mg} \mathrm{L}^{-1}$ of xanthate, $\mathrm{Jl}$ of $0.31 \mathrm{~cm} / \mathrm{s}$ and $30 \mathrm{mg} \mathrm{L}^{-1}$ of surfactant. The surfactant's and the collector's decrease effect is clearly noticeable, and the recovery decreases with each flotation stage, just like the effect that takes place with gas holdup (Fig. 9), which decreases because of the superficial tension's increase.

In some tests the effect of the sparger malfunction was also studied in the copper ion flotation. It was a simulated malfunction, and was carried out by disconnecting a sparger 

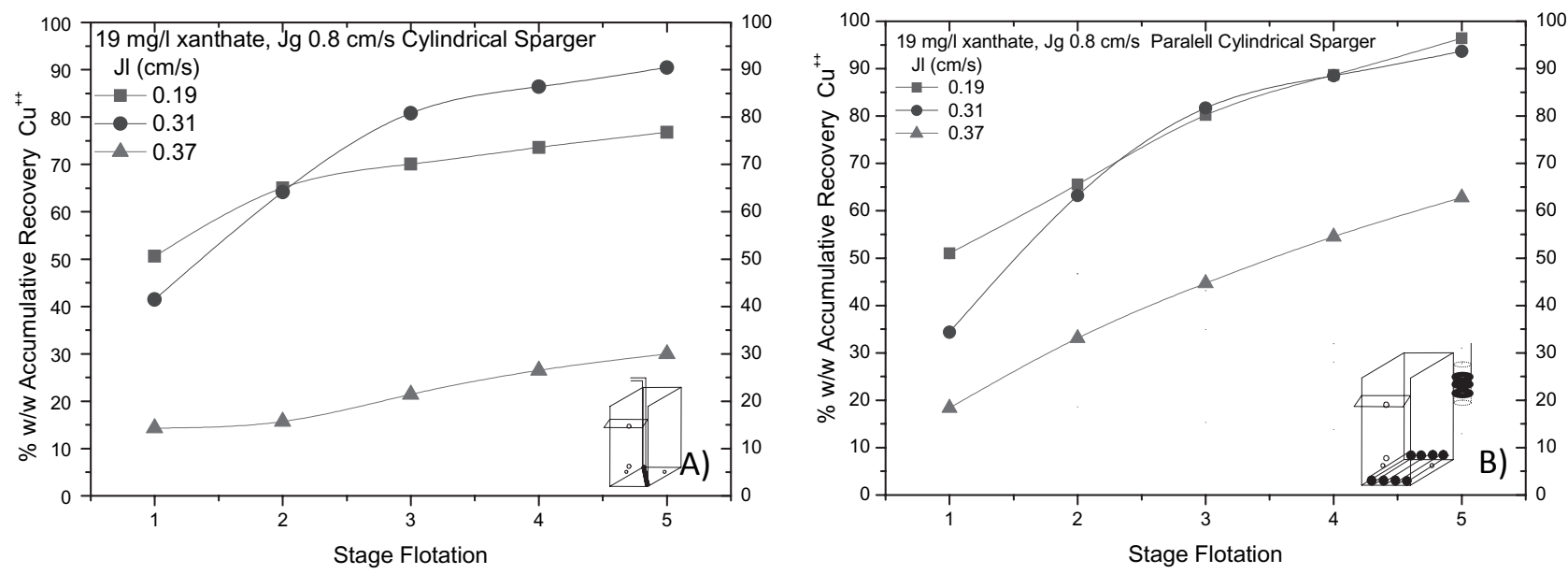

Fig. 12. $\% \mathrm{w} / \mathrm{w}$ Accumulative Recovery $\mathrm{Cu}^{2+}$ vs. Stage flotation. A) Cylindrical sparger. B). Battery of four spargers. Jg $0.8 \mathrm{~cm} / \mathrm{s} 19 \mathrm{mg} \mathrm{L}^{-1}$ of xanthate and $20 \mathrm{mg} \mathrm{L}^{-1}$ of copper

in the flotation cell. Figure 15 presents the results obtained from these experiments; we observed that the accumulative percentage of the copper recovery does not have a significant variation in the fifth stage for the tests where no sparger was connected. When disconnecting sparger 2 and 4 separately and when simulating their simultaneous malfunction, the separation efficiencies in the fifth stage were of $91 \%, 92 \%, 94 \%$ and $93 \%$ respectively, so, even if the simulated malfunction of the sparger modifies the flows of the disperse and continuous phases in the tested flotation system, equilibrium is achieved, and the bubbles that are not generated in the disconnected sparger are generated in the working spargers. This simulated malfunction causes the gas holdup to be lower in the region just above the disconnected sparger.

The graphs show that the best separation efficiency of copper-xanthate complexes by ion flotation techniques is found in a wide range of hydrodynamic conditions in the cell,

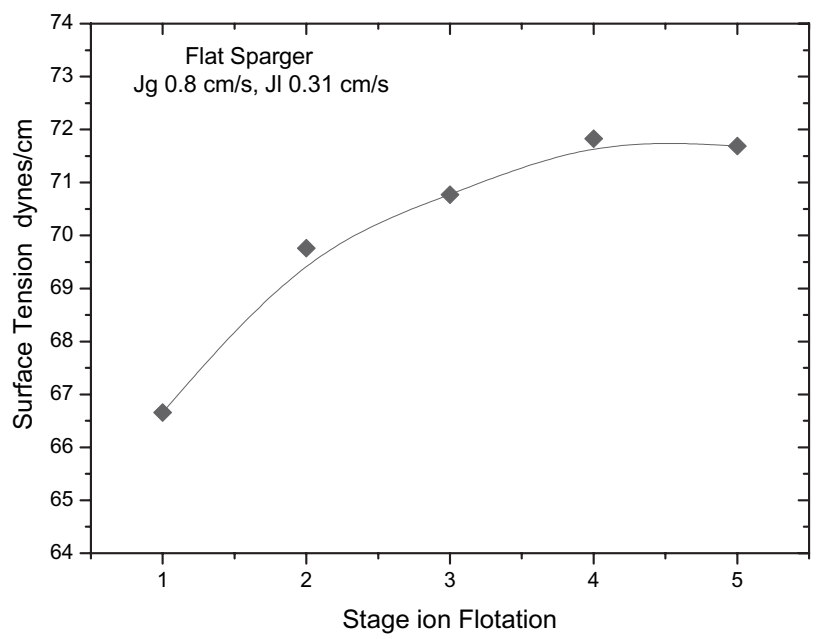

Fig. 13. Surface tension dynes/cm vs. stage ion flotation, flat sparger, $\mathrm{J} 131 \mathrm{~cm} / \mathrm{s}$.

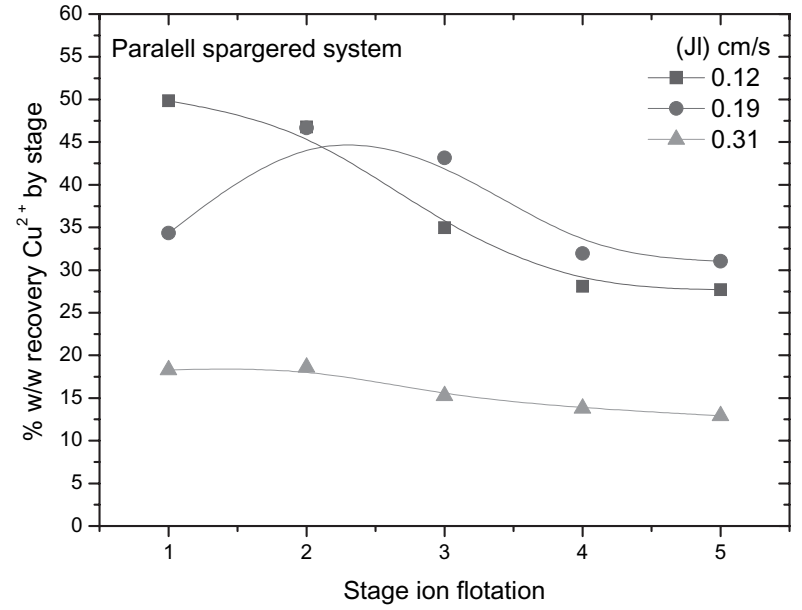

Fig. 14. \% w/w Recovery $\mathrm{Cu}^{2+}$ by stage $v s$. Flotation stage. Battery of four spargers $\mathrm{Jg} 0.8 \mathrm{~cm} / \mathrm{s}$ at several Jl's. $19 \mathrm{mg} \mathrm{L}^{-1}$ of xanthate and 20 $\mathrm{mg} \mathrm{L}^{-1}$ of copper.

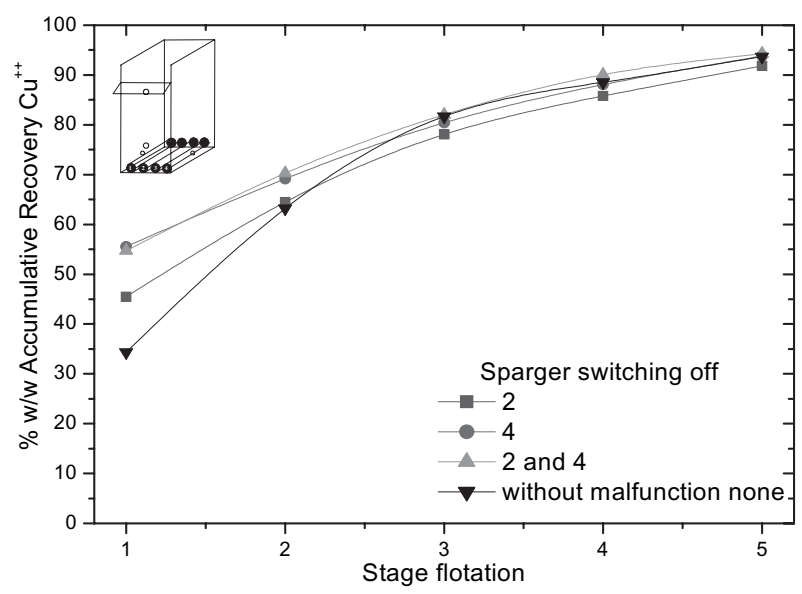

Fig. 15. \% w/w Accumulative Recovery $\mathrm{Cu}^{2+}$ vs. Flotation stage. Effect of the sparger's malfunction $\mathrm{Jg} 0.8 \mathrm{~cm} / \mathrm{s}, \mathrm{Jl} 0.19 \mathrm{~cm} / \mathrm{s}, 20 \mathrm{mg} \mathrm{L}^{-1}$ of copper and $19 \mathrm{mg} \mathrm{L}^{-1}$ of xanthate. 
thus giving different metallurgical answers, which can be favorable or not.

\section{Conclusions}

The copper recovery was carried out in aqueous media by ion flotation techniques in a laboratory flotation cell. The dispersion properties and the hydrodynamic conditions of the process were obtained. The recovery results show that the increase of the potassium amyl xanthate concentration over the stoichiometric concentration of copper considerably affects the separation efficiency. Recoveries of $58 \%$ and $66 \%$ were obtained for the one-stage ion flotation with the flat and cylindrical geometric systems respectively; we found that the dispersion properties and the bubble specific surface area flux have a behaviour which is linear to the apparent flotation rate constant $(k)$. This behavior is found at $\mathrm{Jg}$ values from 0.1 to $0.8 \mathrm{~cm} / \mathrm{s}$, giving the hydrodynamic conditions to efficiently carry out the ion flotation.

The results of the gas bubble dispersion in a multi stage system showed that gas and liquid superficial velocities, geometry of the dispersion system and the simulated parger malfunction have a significant influence on the copper recovery. The best recoveries obtained in the multi stage system were of $94 \%, 90 \%$ and $95 \%$ for the flat, cylindrical and for the battery of four spargers respectively, with a $\mathrm{Jl}$ of $0.37,0.31$ and 0.12 $\mathrm{cm} / \mathrm{s}$. The $\mathrm{Jg}$ was $0.8 \mathrm{~cm} / \mathrm{s}$, with bubble diameters of around $1.0 \mathrm{~mm}$ and $\mathrm{Sb}$ of 44,36 and $41 \mathrm{~s}^{-1}$, respectively.

\section{Acknowledgments}

The corresponding author wishes to express his gratitude to the following organizations: CONACYT. for scholarships, the Universidad Autónoma del Estado de Hidalgo for the all assessment during the postgraduate studies, the Universidad Michoacana de San Nicolás de Hidalgo and Instituto de Investigaciones Metalúrgicas

\section{References}

1. Tavera, F. J.; Escudero, R.; Uribe, A.; Finch, J. A. Afinidad 2000, LVII 490, 415-423.

2. Sebba, F. Nature 1959, 164, 1062-1063.

3. Sebba, F. Ion flotation, Elsevier: London, 1962.

4. Doyle F. Int. J. Miner. Process. 2003, 72, 387-399.

5. Zhendong, L.; Doyle, F. M. J. Colloid Interf. Sci. 2003, 258, 396-403.

6. Zhendong, L.; Doyle, F. M. Colloid Surface, A 2001, 178, 79-92.

7. Zhendong, L.; Doyle, F. M. Colloid Surface, A 2001, 178, 93-103.

8. Hualing, D.; Zhide, H. Talanta 1989, 36, 633-637.

9. Polat, H.; Erdogan, D. J. Hazar. Mater. 2007, 148, 267-273.

10. Zouboulis, A. I. Miner. Eng. 1995, 12, 1477-1148.

11. Galvin, K. P.; Nicol, S. K.; Waters, A. G. Colloid Surface $\mathbf{1 9 9 2 ,}$ 64, 21-33.

12. Hernandez Expósito, A.; Chimenos, J. M.; Fernández, A. I.; Font, O.; Querol, X.; Coca, P.; García Peña F. Chem. Eng. J. 2006, 118, 69-75.

13. Ulewicz, M.; Walkowiak, W.; Bartsch, R. A. Sep. Purif. Technol. 2006, 4, 264-269.

14. Tavera, F. J.; Gomez, C. O.; Finch, J. A. Can. Metall. Quart. 1998, 37, 19-25.

15. Tavera, F. J.; Escudero, R. Trans. Instn. Min. Metall. Sect C 2002, $111,94-99$.

16. Lelinski, D.; Allen, J.; Redden, L.; Web, A. Miner. Eng. 2002, 15, 499-505.

17. Finch, J. A.; Dobby, G. S. Column flotation, Pergamon Press: Oxford, 1990.

18. Laskowski, J. S. Miner. Process. Extr. Metall. 1993, 12, 61-89.

19. http://www.sc.ehu.es accessed in February, 2009. 